\title{
Nominal Price Anomaly in Emerging Markets: Risk or Mispricing?*
}

\author{
Lai Trung HOANG ${ }^{1}$,Trang Thu PHAN ${ }^{2}$, Linh Nhat TA ${ }^{3}$
}

Received: June 16, 2020 Revised: July 19, 2020 Accepted: August 10, 2020

\begin{abstract}
This study examines the nominal price anomaly in the Vietnamese stock market, that is, whether stocks with low nominal price outperform stocks with high nominal price. Using a sample of all 351 companies listed on the Ho Chi Minh Stock Exchange (HOSE) from June 2009 to March 2018, we confirm our hypothesis and document that cheaper stocks yield higher subsequent abnormal returns. The results are robust after controlling for various stock characteristics that have been documented to be value-relevant in prior literature, including firm size, bookto-market ratio, intermediate-term momentum, short-term reversal, skewness, market risk, idiosyncratic risk, illiquidity and extreme daily returns, using both the portfolio analysis and the Fama-MacBeth cross-sectional regression. The negative effect persists in the long term (i.e., after up to 12 months), implying a slow adjustment of stock prices to their intrinsic value. Further analysis show that the observed nominal price anomaly is mainly driven by mispricing but not a latent risk factor proxied by stock price, thus the observed anomaly reflects a mispricing but not a fundamental risk. The study highlights the irrational behaviour of investors and market inefficiency in the Vietnamese stock market and provides important implication for investors in the market.
\end{abstract}

Keywords: Nominal Price Anomaly, Irrational Behaviour, Market Efficiency, Mispricing, Vietnamese Stock Market

JEL Classification Code: G12, G15, G34

\section{Introduction}

Since firms can easily manipulate their stock prices by altering the number of stocks outstanding through a stock split or a reverse stock split without changing firms' market capitalisation and other fundamentals, in an efficient and frictionless market, nominal stock prices should be irrelevant to firm value and stock returns. However, prior literature shows that investors do take nominal price into

\footnotetext{
*Acknowledgements:

This research is funded by the National Economics University, Hanoi, Vietnam.

${ }^{1}$ First Author and Corresponding Author.Lecturer, School of Banking and Finance, National Economics University, Vietnam [Postal Address: 207 GiaiPhong, Hai Ba Trung District, Hanoi,Vietnam] Email: laiht@neu.edu.vn

${ }^{2}$ Lecturer, School of Banking and Finance, National Economics University, Vietnam. Email: trangpt@neu.edu.vn

${ }^{3}$ Lecturer, School of Banking and Finance, National Economics University, Vietnam. Email: linhtn@neu.edu.vn

(C) Copyright: The Author(s)

This is an Open Access article distributed under the terms of the Creative Commons Attribution Non-Commercial License (https://creativecommons.org/licenses/by-nc/4.0/) which permits unrestricted non-commercial use, distribution, and reproduction in any medium, provided the original work is properly cited.
}

consideration during their valuation process. For example, Green and Hwang (2009) show that investors categorise stocks based on their nominal prices. Schultz (2000) finds that after a stock split, the number of small shareholders in the firm tends to increase, implying that individual investors generally prefer low price stocks. Birru and Wang (2016) explain this preference by providing evidence that investors systematically overestimate the skewness of low price stocks, and generally suffer from the illusion that low price stocks have more upside potential. Interestingly, firms seem to be also aware of this phenomenon: they actively manage their stock price levels to maximise firm value. For example, Baker, Greenwood, and Wurgler (2009) show that firms are more likely to carry out stock splits to artificially boost their stock prices when valuation of low-priced stocks is higher than that of high-priced stocks. Likewise, Dyl and Elliott (2006) find evidence that firms manipulate their share prices to increase the value of the firms.

From a market-wide perspective, if investors irrationally overvalue high price stocks, the prices should eventually reverse and yield negative abnormal returns. Consistent with this hypothesis, several studies document that high price stocks underperform low price stocks in the U.S. market (e.g., Disli, Inghelbrecht, Schoors, \&Stieperaere, 
2019; Edmister\& Greene, 1980; Goodman \&Peavy, 1986; Hwang \& Lu, 2008), evidence outside the U.S. (especially in emerging countries where the stock markets are less efficient) is sparse. If the nominal price anomaly is driven by the illusion and irrational behaviour of investors, it is expected that the anomaly should be more significant in less efficient markets. Pastusiak, Jasiniak, and Plustoka (2019) analyse 764 mergers and acquisitions (M\&A) transactions in Poland from 2005 to 2015 and find that investments in low price stocks are more likely to generate higher profits than investments in high price stocks. However, the study does not attempt to control for other firm characteristics that possibly leads to spurious results. Interestingly, a more in-depth study by Zaremba, Okoń, Nowak, and Konieczka (2016) on the Polish stock market documents that high price stocks significantly outperform low price stocks. Since low price stocks in their sample generally have lottery-like characteristics (e.g., high volatility, high growth, highly positive skewness), the authors suggest that the positive relationship might be driven by the underperformance of the lottery-like stocks. However, since the double-sorting portfolio analysis applied in their study is unable to disentangle effects of multiple firm-level characteristics, the truly meaningful effect behind the result is of uncertainty.

Motivated by these conflicting results, this study reexamines the nominal price anomaly in the Vietnamese stock market by applying more in-depth methodologies. This emerging market has some unique features that make the price-returns relationship worth to revisit. First, the market is relatively young and therefore is dominated by individual investors who have strong preference for low price stocks. According to the Vietnam Securities Depository, at the end of March 2018, out of more than 2 million trading accounts, only around 11,700 accounts (approximately $0.6 \%$ ) belong to institutional investors. Second, the Vietnamese market is one of the fastest growing market in the world during recent years. VN-Index, the benchmark index of the market, gained $15 \%$ in 2016 , and $47 \%$ in 2017 . Third, in spite of experiencing a rapid growth, the market is still relatively small compared to other international and regional markets. Forth, many prior studies have documented that the Vietnamese stock market is inefficient, for example Nguyen and Pham (2018), Nguyen and Nguyen (2019), and Vu, Phan, and Dang (2020). Such characteristics might lead to different behaviours of investors, which is an important determinant of the pricereturn relationship.

Using a sample of 351 companies listed on the Ho Chi Minh Stock Exchange (HOSE) from June 2009 to March 2018, we find a negative relationship between stocks' nominal prices and their subsequent raw and riskadjusted returns. The results are robust after controlling for various stock characteristics that have been documented to be value-relevant, including firm size, book-to-market ratio, intermediate-term momentum, short-term reversal, skewness, market risk, idiosyncratic risk, illiquidity and extreme daily returns. The negative relation persists for at least 12 months, suggesting a slow adjustment of stock price to its intrinsic value - a strong signal of market inefficiency. Further analysis suggests that it is the nominal price characteristic rather than the nominal price factor loading that predicts abnormal returns, suggesting that the anomaly is driven by mispricing but not a latent risk factor proxied by the nominal price.

The rest of the paper is structured as follow. Section 2 describes data and methodology. Section 3 presents the estimation results, followed by robustness tests in Section 4 . Section 5 concludes.

\section{Data and Methodology}

We collect data of all 351 stocks listed on the Ho Chi Minh Stock Exchange (HOSE) from June 2009 to March 2018 from Bloomberg. To avoid the survival bias, we also include in our analysis all stocks that had been delisted during the sample period. Our sample starts from June 2009 as the Vietnam interbank-offered rate (VNIBOR) which is used as the proxy for risk-free rate was only available in Bloomberg from that time. The monthly nominal stock price is measured by the closing price at the end of each month. Monthly returns are computed as the difference of the natural $\log$ of monthly closing prices.

In the main tests, we employ the standard portfolio analysis and cross-sectional Fama and MacBeth (1973) regressions to examine the relationship between nominal stock prices and subsequent returns. Specifically, for portfolio analysis, we sort stocks into quintiles based on their monthly closing prices, then estimate subsequent monthly returns of each portfolio. Along with raw returns which are derived from the changes of stock prices, risk-adjusted returns are also estimated as the intercept $(\alpha)$ in the liquidityaugmented Fama and French (1993) four-factor model (1). Hoang and Phan (2019)analyse different alternative asset pricing models in the Vietnamese stock market and suggest that the liquidity-augmented Fama-French (1993) fourfactor model outperforms others in explaining stock returns.

$$
R_{i}-R_{f}=\alpha+\beta\left(R_{m}-R_{f}\right)+s S M B+h H M L+\psi L I Q+\varepsilon_{i}
$$

where $R_{i}$ is value-weighted average monthly returns of portfolios constructed from nominal prices, and $R_{f}$ is the monthly risk-free rate proxied by Vietnam interbank offered rate (VNIBOR) collected from Bloomberg. The market returns, $R_{m}$, is measured by monthly returns of 
VN-Index - the value-weighted index of all stocks listed on the HOSE. Size factor $(S M B)$, value factor $(H M L)$ and liquidity factor $(L I Q)$ are the differences between monthly returns of small versus big, value versus growth, and illiquid versus liquid stocks, respectively. We follow Fama and French (1993) to construct $S M B$ and $H M L$ factors, but instead of June we use data at the end of December to form portfolios, since only end-of-year financial reports are audited and thus are more reliable. $L I Q$ is constructed following Hoang and Phan (2019) as the difference between returns of the least and the most liquid stock terciles.

We further adopt the double sorting method to control for other stock characteristics that potentially affect stock returns, including firm size (SIZE), book-to-market ratio $(B M)$, intermediate-term momentum ( $M O M)$, short-term reversal (REV), skewness (ISKEW and SSKEW), market risk (BETA), idiosyncratic risk (IVOL), illiquidity (ILLIQ) and extreme daily returns $(M A X)$. At the end of each month, we first sort stocks into quintiles based on each of aforementioned stock characteristics, then within each quintile we sort stocks into quintiles again based on their nominal prices, resulting in $5 \times 5$ double-sorted portfolios. Next, following Nartea, Kong, and Wu (2017), portfolios with the same level of nominal prices across control characteristic quintiles are regrouped, resulting in five portfolios with similar levels of the control characteristic but various levels of nominal price. Then similar to the single sorting approach, we compute and assess average raw returns and risk-adjusted returns with regard to the liquidityaugmented Fama-French (1993) model (1) of those doublesorted portfolios.

For each firm-month observations, we construct a set of control variables as follows. Firm size (SIZE) is measured by the stock's market capitalization at the end of the month. $B M$ is the book-to-market ratio six months before. Momentum $(M O M)$ at the beginning of month $t$ is the 11-month past return lagged one month, i.e. the change of log prices from month $t-12$ to month $t-2$. Short-term reversal $(R E V)$ is the return in the previous month. Market risk (BETA) in month $t$ is estimated slope of the traditional CAPM using daily returns in month $t-1$, while idiosyncratic risk (IVOL) in month is estimated as the standard deviation of residuals of the liquidity-augmented Fama-French model (1) ( $(\varepsilon)$ using daily returns in month $t-1$. Following Bali, Cakici, and Whitelaw (2011), MAX for each month is the highest daily returns during the previous month.

We use the proxy developed by Amihud (2002) to measure stock illiquidity:

$$
I L L I Q_{i, t}=\frac{1}{d a y_{i, t}} \sum_{d=1}^{d a y_{i, t}} \frac{\left|R_{i, d, t}\right|}{\operatorname{Vol}_{i, d, t}}
$$

where $\left|R_{i, d, t}\right|$ and $\operatorname{Vol}_{i, d, t}$ are the absolute values of returns and trading volume of stock $i$ on day $d$ of month $t$, and $d a y_{i, t}$ is the number of days in month $t$ for which data of returns and trading volumes of stock $i$ are available.

Following Harvey and Siddique (2000), we break return skewness into systematic skewness (SSKEW) and idiosyncratic skewness (ISKEW) by estimating the equation (2) using daily returns within each month:

$$
R_{i}-r_{f}=\alpha_{i}+\beta_{i}\left(R_{m}-r_{f}\right)+\gamma_{i}\left(R_{m}-r_{f}\right)^{2}+\epsilon_{i}
$$

where $R_{i, d}$ is the return of stock $i$ on day $d, r_{f, d}$ is the risk-free rate on day $d, R_{m, d}$ is the market return on day $d$. SSKEW of stock $i$ at the beginning of each month is the estimated value of $\hat{\gamma}_{i}$ using daily returns in the previous month, while ISKEW is the skewness of the estimated residuals $\hat{\epsilon}_{i}$.

Although the double sorting illustrates a feasible investment strategy that exploits the potential nominal price anomaly while controlling for a particular stock characteristic, it is unable to control for multiple factors simultaneously. Thus, we supplement our analysis by applying the standard cross-sectional Fama-MacBeth regression to examine the robustness of the portfolio analysis results. Specifically, each month from June 2009 to March 2018, we run a crosssectional regression of monthly stock returns on the nominal prices at the end of last month and various control variables, resulting a time series of estimated coefficients for each regressor. Averages of those estimated coefficients along with their corresponding t-statistics will be used to assess the significance of the effects of nominal price and each stock characteristic on subsequent returns.

\section{Empirical Results}

\subsection{Portfolio Analysis}

Table 1 presents the time-series average of raw and riskadjusted returns of five portfolios sorted on nominal stock price at the end of the last month. The results show that generally returns decrease as the nominal prices increase, thus low price portfolios outperform high price portfolios in terms of both raw returns and risk-adjusted returns. The differences between returns of lowest price and highest price portfolios are positive and statistically significant at 10 percent level in case of raw returns and at 1 percent level for risk-adjusted returns, implying that the long-short strategy that buys cheap stocks and sells expensive stocks is profitable. Numerically, the strategy can yield 1.1 percent raw returns or 1.4 percent risk-adjusted returns per month, which can be converted into 13.2 percent and 17 percent per year respectively. The results strongly support the negative relationship between nominal stock prices and subsequent returns, which is consistent with the findings of Hwang and $\mathrm{Lu}(2008)$ in the U.S. stock market. 
Table 1: Performance of portfolios sorted on closing prices

\begin{tabular}{|l|c|c|}
\hline & Raw Returns & $\begin{array}{c}\text { Risk-adjusted } \\
\text { returns }\end{array}$ \\
\hline Low Price & 0.012 & -0.004 \\
\hline 2 & $(1.595)$ & $(-1.016)$ \\
\hline & 0.005 & $-0.011^{* *+}$ \\
\hline 3 & $(0.711)$ & $(-3.093)$ \\
\hline & 0.002 & $-0.012^{* * *}$ \\
\hline 4 & $(0.414)$ & $(-3.776)$ \\
\hline & 0.003 & $-0.010^{* * *}$ \\
\hline High Price & $(0.531)$ & $(-2.866)$ \\
\hline & 0.002 & $-0.013^{* * *}$ \\
\hline Low - High & $(0.365)$ & $(-4.21)$ \\
\hline & $0.010^{*}$ & $0.014^{* * *}$ \\
\hline
\end{tabular}

Note: This table presents time-series averages of returns of portfolios sorted on previous month closing prices. At the end of each month from 2009:07 to 2018:03, we sort stocks into quintiles based on their nominal prices, then compute the value-weighted average returns of those portfolios in the next month. Risk-adjusted returns are defined as estimated intercepts in the liquidityaugmented Fama-French (1993) model (1) using monthly returns. Low (High) Price refers to the portfolio of stocks in the lowest (highest) price quintile. Portfolios are rebalanced every month. t-statistics are in parentheses. ", "* , and ${ }^{* * *}$ denote significance levels of $10 \%, 5 \%$ and $1 \%$ respectively.
Although the results from Table 1 are consistent with the nominal price anomaly, they do not automatically confirm it. It is possible that the observed effects might come from high correlations of stock price with other value-relevant stock characteristics. Table 2 shows that such correlations exist. Low price stocks are generally smaller, less liquid, riskier (in terms of both market and idiosyncratic risks), have higher book-to-market value, lower momentum and higher extreme daily returns. In addition, previous returns of low price stocks tend to be smaller and less positively skewed than that of high price stocks. The correlations are strongly significant with absolute values of t-statistics of the differences between the lowest and the highest price quintiles are mostly larger than 4.

Since a number of studies have documented potential effects of those stock characteristics on stock returns (see, for example, Lintner (1965) for market beta, Fama and French (1993) for size and book-to-market, Carhart (1997) for momentum, Amihud (2002) for illiquidity, Ang, Hodrick, Xing, and Zhang (2006) for idiosyncratic volatility, Bali et al. (2011) for extreme returns effects), we perform a double sorting procedure to control for those possible confounding effects. Details of the double sorting method are described in Section 2. The results in Table 3 show that the returns generally decrease when going from the lowest price portfolio to the highest. More importantly, all risk-adjusted returns (alphas) of the longshort portfolios based on the nominal price are strongly statistically significant, mostly at 1 percent level. Thus, even after controlling for various stock characteristics,

Table 2: Characteristics of price portfolios

\begin{tabular}{|l|c|c|c|c|c|c|c|c|c|c|c|}
\hline & CP & SIZE & BM & MOM & REV & SSKEW & ISKEW & IVOL & BETA & ILLIQ & MAX \\
\hline Low CP & 4.438 & 19.097 & 2.161 & -0.112 & -0.017 & -5.796 & 0.066 & 0.026 & 0.732 & 0.038 & 0.050 \\
\hline 2 & 7.693 & 19.652 & 1.408 & 0.017 & -0.001 & -6.308 & 0.096 & 0.024 & 0.732 & 0.021 & 0.048 \\
\hline 3 & 11.425 & 20.145 & 1.090 & 0.091 & 0.008 & -5.97 & 0.131 & 0.022 & 0.704 & 0.014 & 0.046 \\
\hline 4 & 17.638 & 20.686 & 0.828 & 0.163 & 0.012 & -4.681 & 0.140 & 0.021 & 0.671 & 0.009 & 0.045 \\
\hline High CP & 38.044 & 21.455 & 0.543 & 0.230 & 0.020 & -4.029 & 0.143 & 0.020 & 0.609 & 0.005 & 0.044 \\
\hline Low - High & -33.61 & -2.36 & 1.62 & -0.34 & -0.04 & -1.77 & -0.077 & 0.006 & 0.12 & 0.033 & 0.006 \\
\hline & $(-20.48)$ & $(-61.92)$ & $(25.02)$ & $(-16.99)$ & $(-6.92)$ & $(-0.88)$ & $(-4.64)$ & $(15.45)$ & $(4.51)$ & $(14.80)$ & $(10.23)$ \\
\hline
\end{tabular}

Note: This table presents characteristics of portfolios sorted on monthly closing prices. At the beginning of each month $t$ from $2009: 07$ to 2018:03, we sort stocks into quintiles based on their most recent closing prices, then portfolio characteristics are computed as the average of all stocks in the portfolio. CP is the closing price measured in thousand VND. SIZE is the log of market capitalization at the end of the previous month $t-1$. $B M$ is book-to-market ratio six months prior, i.e. in month $t-6$. MOM is the return momentum, measured as 11 -month return lagged one month, i.e. return from month $t-12$ to month $t-2$. REV is the return in month $t-1$. SSKEW is co-skewness, ISKEW is idiosyncratic skewness, IVOL is idiosyncratic volatility, BETA is market risk, ILLIQ is Amihud (2002) illiquidity proxy, and MAX is maximum daily returns in month $t-1$. The last row reports the differences between characteristics of the highest and the lowest closing price portfolio $\mathrm{t}$-statistics in parentheses. Bold numbers represent the significance level of $1 \%$. 
the significant difference in returns between expensive stocks and cheap stocks persist. This evidence further validates the existence of the nominal price anomaly in the Vietnamese stock market. For the sake of brevity, we only report average risk-adjusted returns with regards to model (1). The results for raw returns are qualitatively similar and will be available upon request.

\subsection{Firm-Level Cross-Sectional Regression}

Although the univariate and bivariate sortings are easy to implement and interpret, the process loses too much information through aggregation and fails to control for multiple effects simultaneously (Nartea et al., 2017). To overcome those shortcomings, we conduct a cross-sectional Fama-MacBeth regression using the model (3):

$$
\begin{aligned}
R_{i, t}= & \beta_{0}+\beta_{1} C P_{i, t-1}+\beta_{2} \operatorname{SIZE}_{i, t-1}+\beta_{3} B M_{i, t-1} \\
& +\beta_{4} M_{i, t-1}+\beta_{5} R E V_{i, t-1}+\beta_{6} S S K E W \\
& +\beta_{7} I S K E W+\beta_{8} I V O L_{i, t-1}+\beta_{9} B E T A \\
& +\beta_{10} I L L I Q_{i, t-1}+\beta_{11} M A X_{i, t-1}+\varepsilon_{1, t-1}
\end{aligned}
$$

Each month from June 2009 to March 2018, we regress monthly stock returns on stock characteristics at the end of the previous month, including closing price $(C P), \log$ of market capitalization (SIZE), book-to-market ratio $(B M)$, momentum (MOM), short-term reversal (REV), co-skewness (SSKEW), idiosyncratic skewness (ISKEW), idiosyncratic volatility (IVOL), market beta (BETA), illiquidity (ILLIQ)

\begin{tabular}{|c|c|c|c|c|c|c|}
\hline & Low Price & 2 & 3 & 4 & High Price & Low - High \\
\hline \multirow{2}{*}{$\begin{array}{l}\text { Size and } \\
\text { Closing Price }\end{array}$} & -0.004 & $-0.01^{\prime * *}$ & $-0.009^{* * *}$ & $-0.011^{m+*}$ & $-0.016^{*+* *}$ & $0.017^{*+* x}$ \\
\hline & $(-0.985)$ & $(-3.077)$ & $(-2.812)$ & $(-3.509)$ & $(-4.832)$ & $(5.617)$ \\
\hline \multirow{2}{*}{$\begin{array}{l}\text { BM and Closing } \\
\text { Price }\end{array}$} & -0.002 & $-0.008^{* *}$ & $-0.012^{* * *}$ & $-0.013^{+* *+}$ & $-0.013^{*+* *}$ & $0.016^{*+* x}$ \\
\hline & $(-0.654)$ & $(-2.488)$ & $(-4.139)$ & $(-4.115)$ & $(-3.719)$ & (5.109) \\
\hline \multirow{2}{*}{$\begin{array}{l}\text { MOM and } \\
\text { Closing Price }\end{array}$} & -0.004 & -0.006 & $-0.008^{* *}$ & $-0.012^{* * * *}$ & $-0.012^{* * *}$ & $0.013^{*+* x}$ \\
\hline & $(-1.105)$ & $(-1.674)$ & $(-2.624)$ & $(-3.842)$ & $(-3.804)$ & $(4.295)$ \\
\hline \multirow{2}{*}{$\begin{array}{l}\text { REV and } \\
\text { Closing Price }\end{array}$} & -0.003 & $-0.009^{* * *}$ & $-0.011^{*+* *}$ & $-0.012^{+* * *}$ & $-0.013^{* * *}$ & $0.015^{*+* x}$ \\
\hline & $(-0.905)$ & $(-2.638)$ & $(-3.221)$ & $(-3.681)$ & $(-4.334)$ & (4.69) \\
\hline \multirow{2}{*}{$\begin{array}{l}\text { SSKEW and } \\
\text { Closing Price }\end{array}$} & -0.004 & $-0.012^{* * *}$ & $-0.01^{* * * *}$ & $-0.011^{* * *}$ & $-0.013^{* * *+}$ & $0.014^{*+* x}$ \\
\hline & $(-0.967)$ & $(-3.318)$ & $(-2.887)$ & $(-3.422)$ & $(-4.297)$ & $(4.602)$ \\
\hline \multirow{2}{*}{$\begin{array}{l}\text { ISSKEW and } \\
\text { Closing Price }\end{array}$} & -0.003 & $-0.011^{\text {tw+ }}$ & $-0.011^{* * * t}$ & $-0.01^{* * *+}$ & $-0.013^{* * * t}$ & $0.015^{* * * x}$ \\
\hline & $(-0.915)$ & $(-3.398)$ & $(-3.096)$ & $(-3.198)$ & $(-4.398)$ & (4.688) \\
\hline \multirow{2}{*}{$\begin{array}{l}\text { IVOL and } \\
\text { Closing Price }\end{array}$} & -0.003 & $-0.01^{\prime * * *}$ & $-0.01^{*+*}$ & $-0.012^{* * *}$ & $-0.015^{* * *}$ & $0.017^{* * x}$ \\
\hline & $(-0.691)$ & $(-2.884)$ & $(-2.913)$ & $(-3.311)$ & $(-5.101)$ & $(5.380)$ \\
\hline \multirow{2}{*}{$\begin{array}{l}\text { BETA and } \\
\text { Closing Price }\end{array}$} & -0.003 & $-0.012^{* * *}$ & $-0.01^{* * *}$ & $-0.01^{* * *+}$ & $-0.014^{* * *}$ & $0.017^{+* * x}$ \\
\hline & $(-0.785)$ & $(-3.397)$ & $(-2.92)$ & $(-2.825)$ & $(-4.944)$ & (5.281) \\
\hline \multirow{2}{*}{$\begin{array}{l}\text { ILLIQ and } \\
\text { Closing Price }\end{array}$} & -0.004 & $-0.012^{+* *+}$ & $-0.011^{* * *+}$ & $-0.011^{*+*}$ & $-0.012^{+* *+}$ & $0.014^{*+* t}$ \\
\hline & $(-1.071)$ & $(-3.549)$ & $(-3.207)$ & $(-3.229)$ & $(-4.27)$ & $(4.307)$ \\
\hline
\end{tabular}
and the maximum aggregate daily returns $(M A X)$. Definitions of these variables are described in Section 2.

Table 3: Risk-adjusted returns of double-sorted portfolios

Note: This table presents risk-adjusted returns of portfolios double-sorted on a control variable and monthly nominal price. For each control variable, at the end of each month, we sort stocks into quintiles based its most recent value. Definitions of control variables are in Table 2. Next, within each quintile, we sort stocks into quintiles again based on nominal prices. Then, we combine groups with the same level of prices across quintiles of control variable, resulting in 5 portfolios with various levels of price but similar levels of the control variable. Then value-weighted average returns of the five portfolios in the next month are computed. Portfolios are rebalanced every month, resulting in time-series of monthly average returns of each price portfolios. The table reports alphas of the liquidity-augmented FF3-model (1) using those time-series returns, as well as the average differences between alphas of the highest and the lowest price portfolios. t-statistics are in parentheses. " " , and ${ }^{* * *}$ denote significance levels of $10 \%, 5 \%$ and $1 \%$ respectively. 
Table 4 reports the time-series averages of the bivariate and multivariate Fama-MacBeth regression coefficients over the 105-month period. In all bivariate and multivariate regressions when stock characteristics are properly controlled, the coefficients of nominal price $(C P)$ are all negative and statistically significant, mostly at 5 percent level. The results strongly support the price anomaly, i.e., nominal stock prices negatively affect subsequent stock returns. Regarding other characteristics, momentum (MOM) and book-to-market ratio $(B M)$ show strong effects on stock returns, with all coefficients being positive and statistically significant at 1 percent level. ISKEW and IVOL coefficients are negative and significant in bivariate regressions, but becomes insignificant in a multivariate setting. Other characteristics are insignificant thus not playing a significant role in determining stock returns in the Vietnamese stock market.

\section{Robustness Tests}

\subsection{Risk or Mispricing?}

In this subsection, we further examine whether the observed abnormal returns gained by low price stocks are driven by a latent systematic risk factor which is proxied by stock price or simply reflect the correction of mispricing caused by irrational behaviour. Since a mimicking risk factor is usually built on the anomalous characteristic itself, there is high correlation between them (Hirshleifer, Hou, \& Teoh, 2012). Thus, to distinguish the risk from the mispricing effect, it is essential to examine whether the nominal price-based factor predicts returns after controlling for the nominal price characteristic. To do so, we adopt a test in the spirit of Daniel and Titman (1997). Specifically, we first use the nominal stock price to construct

Table 4: Risk-adjusted returns of double-sorted portfolios

\begin{tabular}{|c|c|c|c|c|c|c|c|c|c|c|c|}
\hline & (1) & (2) & (3) & (4) & (5) & (6) & (7) & (8) & (9) & (10) & (11) \\
\hline \multirow[t]{2}{*}{$\mathrm{CP} \times 10$} & $-0.002^{*}$ & $-0.002^{* *}$ & $-0.003^{* * *}$ & $-0.003^{* *}$ & $-0.003^{* *}$ & $-0.003^{* *}$ & $-0.003^{* *}$ & $-0.003^{* *}$ & $-0.002^{*}$ & $-0.003^{* *}$ & $-0.003^{*+* t}$ \\
\hline & $(-1.779)$ & $(-2.061)$ & $(-2.842)$ & $(-2.357)$ & $(-2.027)$ & $(-2.076$ & $(-2.346)$ & $(-2.444)$ & $(-1.860)$ & $(-2.080)$ & $(-2.856)$ \\
\hline \multirow[t]{2}{*}{ SIZE } & 0.0002 & & & & & & & & & & 0.0002 \\
\hline & $(0.166)$ & & & & & & & & & & $(0.167)$ \\
\hline \multirow[t]{2}{*}{ BM } & & 0.001 & & & & & & & & & $0.005^{* *}$ \\
\hline & & $(0.367)$ & & & & & & & & & $(1.981)$ \\
\hline \multirow[t]{2}{*}{ MOM } & & & $0.017^{* * *}$ & & & & & & & & $0.021^{*+*+}$ \\
\hline & & & (3.583) & & & & & & & & (5.671) \\
\hline \multirow[t]{2}{*}{ REV } & & & & 0.001 & & & & & & & -0.003 \\
\hline & & & & $(0.058)$ & & & & & & & $(-0.196)$ \\
\hline \multirow[t]{2}{*}{ SSKEW } & & & & & -0.0001 & & & & & & -0.00003 \\
\hline & & & & & $(-1.232)$ & & & & & & $(-1.054)$ \\
\hline \multirow[t]{2}{*}{ ISKEW } & & & & & & $-0.003^{*}$ & & & & & -0.002 \\
\hline & & & & & & $(-1.779)$ & & & & & $(-1.098)$ \\
\hline \multirow[t]{2}{*}{ IVOL } & & & & & & & $-0.375^{* \ldots *}$ & & & & -0.218 \\
\hline & & & & & & & $(-2.928)$ & & & & $(-1.150)$ \\
\hline \multirow[t]{2}{*}{ BETA } & & & & & & & & -0.001 & & & 0.003 \\
\hline & & & & & & & & $(-0.337)$ & & & $(1.313)$ \\
\hline \multirow[t]{2}{*}{ ILLIQ } & & & & & & & & & -2.717 & & 341.187 \\
\hline & & & & & & & & & $(-0.234)$ & & $(0.904)$ \\
\hline \multirow[t]{2}{*}{ MAX } & & & & & & & & & & -0.093 & -0.011 \\
\hline & & & & & & & & & & $(-1.536)$ & $(-0.093)$ \\
\hline $\mathrm{R}^{2}$ & 0.205 & 0.212 & 0.214 & 0.212 & 0.199 & 0.199 & 0.202 & 0.210 & 0.208 & 0.200 & 0.279 \\
\hline
\end{tabular}

Note: Each month from 2009:07 to 2018:03, we run a Fama-MacBeth cross-sectional regression of stock returns during that month on control variables at the end of the previous month. Definition of control variables are in Table 2. This table reports time-series averages of estimated slope coefficients and their corresponding t-statistics in parentheses. ${ }^{*},{ }^{* *},{ }^{, * * *}$ denote significant levels of $10 \%, 5 \%$ and $1 \%$ respectively. 
a long-short portfolio to mimic the potential underlying factor driving nominal price anomaly. Analogous to the standard factor construction procedure in prior literature, at the end of each month we sort stocks into terciles based on their closing prices. Then the nominal price-based factor CME (cheap minus expensive) is computed as the difference between returns of the low price portfolio (C) and the high price portfolio (E).

Next, we incorporate CME factor into the liquidityaugmented Fama-French four-factor model to estimate the monthly CME loading $(\rho)$ of each stock using its previous 36 monthly returns ( 24 months minimum). The model is specified as follows:

$$
\begin{aligned}
R_{i}-R_{f}= & \alpha+\beta\left(R_{m}-R_{f}\right)+s S M B+h H M L \\
& +\psi L I Q+\rho C M E+\varepsilon_{i}
\end{aligned}
$$

We next perform the triple sorting procedure based on firm size, nominal price and CME loading. Specifically, at the end of each month, we independently sort stocks into terciles based on their market capitalisations and nominal prices, resulting in 9 double-sorted size/price portfolios. Following Daniel and Titman (1997), Daniel, Grinblatt, Titman, and Wermers (1997) and Hirshleifer et al. (2012), for each size/price portfolio, we construct a zero-investment characteristic-balanced portfolio that is long on the high-CME-loading portfolio (the third CME loading tercile) and short on the low-CME-loading portfolio (the first CME loading tercile). By construction, the variation of returns within each characteristic-balance portfolio is purely driven by the factor loading but not the characteristic (i.e., nominal price). Thus, the intercept in the model (4) (with $R_{i}$ is returns of characteristic-balanced portfolio) is expected to be zero if there exists a latent risk factor driving the nominal price anomaly. In contrast, if the anomaly is driven by mispricing, the intercept should to be negative to counterbalance the positive return premium of the CME factor.

\begin{tabular}{|c|c|c|c|c|c|c|c|}
\hline & Intercept & $\mathbf{R m}-\mathbf{R f}$ & SMB & HML & IML & CME & $\mathbf{R}^{2}$ \\
\hline \multirow[t]{2}{*}{$\mathrm{S} / \mathrm{L}$} & -0.008 & -0.255 & $-0.631^{*}$ & $-1.204^{\star \star *}$ & $-0.612^{\star \star \star}$ & $1.59^{* * *}$ & 0.592 \\
\hline & $(-1.274)$ & $(-1.6)$ & $(-1.977)$ & $(-5.137)$ & $(-2.686)$ & $(7.697)$ & \\
\hline \multirow[t]{2}{*}{ S/M } & 0.009 & $-0.362^{*}$ & $-1.031^{* \star}$ & $-1.408^{* * *}$ & -0.437 & $1.094^{* * * t}$ & 0.254 \\
\hline & (1.099) & $(-1.78)$ & $(-2.533)$ & $(-4.715)$ & $(-1.506)$ & $(4.156)$ & \\
\hline \multirow[t]{2}{*}{$\mathrm{S} / \mathrm{H}$} & -0.009 & -0.209 & -0.668 & $-2.927^{\star \star *}$ & -0.439 & $2.86^{* * *}$ & 0.184 \\
\hline & $(-0.400)$ & $(-0.362)$ & $(-0.542)$ & $(-3.055)$ & $(-0.537)$ & $(3.034)$ & \\
\hline \multirow[t]{2}{*}{$\mathrm{M} / \mathrm{L}$} & -0.006 & -0.223 & 0.105 & $-1.224^{* * *}$ & $-1.114^{* * *}$ & $1.051^{* * *}$ & 0.381 \\
\hline & $(-0.675)$ & $(-1.037)$ & $(0.244)$ & $(-3.866)$ & $(-3.617)$ & (3.767) & \\
\hline \multirow[t]{2}{*}{$\mathrm{M} / \mathrm{M}$} & $-0.023^{* \star *}$ & -0.013 & -0.486 & $-1.21^{\star \star \star}$ & -0.158 & $1.323^{\star * *}$ & 0.326 \\
\hline & $(-3.047)$ & $(-0.068)$ & $(-1.29)$ & $(-4.377)$ & $(-0.588)$ & $(5.428)$ & \\
\hline \multirow[t]{2}{*}{$\mathrm{M} / \mathrm{H}$} & $-0.015^{* *}$ & -0.107 & -0.359 & $-0.680^{* *}$ & -0.158 & $0.977^{* * *}$ & 0.258 \\
\hline & $(-2.071)$ & $(-0.595)$ & $(-0.997)$ & $(-2.57)$ & $(-0.614)$ & $(4.193)$ & \\
\hline \multirow[t]{2}{*}{$B / L$} & -0.008 & -0.357 & -0.57 & $-1.691^{* * *}$ & -0.339 & $1.404^{*+* x}$ & 0.269 \\
\hline & $(-0.789)$ & $(-1.459)$ & $(-1.163)$ & $(-4.706)$ & $(-0.971)$ & $(4.43)$ & \\
\hline \multirow[t]{2}{*}{$\mathrm{B} / \mathrm{M}$} & $-0.024^{* * *}$ & 0.326 & $-0.938^{* *}$ & $-1.035^{\star * *}$ & $0.570^{*}$ & $1.382^{* * *}$ & 0.253 \\
\hline & $(-2.751)$ & $(1.475)$ & $(-2.118)$ & $(-3.184)$ & $(1.802)$ & $(4.824)$ & \\
\hline \multirow[t]{2}{*}{$\mathrm{B} / \mathrm{H}$} & $-0.009^{*}$ & -0.099 & $-1.046^{* * *}$ & $-1.353^{* * * *}$ & 0.009 & $1.467^{* * * *}$ & 0.547 \\
\hline & $(-1.877)$ & $(-0.803)$ & $(-4.242)$ & $(-7.475)$ & $(0.049)$ & $(9.196)$ & \\
\hline \multirow[t]{2}{*}{ Combined } & $-0.010^{* * *}$ & -0.150 & $-0.564^{* * *}$ & $-1.323^{* * *}$ & $-0.334^{* *}$ & $1.360^{* * *}$ & 0.686 \\
\hline & $(-2.709)$ & $(-1.609)$ & $(-3.014)$ & $(-9.644)$ & $(2.503)$ & $(11.250)$ & \\
\hline
\end{tabular}

Table 5: Regression results for characteristic-balance portfolios formed from triple sorts on size, nominal price and CME loading

Note: At the end of each month, stocks with at least 24 months of returns in the previous three years are independently sorted into size terciles (S, M, B) and price terciles (L, M, H). The intersections result in nine size/price portfolios (S/L, S/M, S/H, M/L, M/M, M/H, B/L, B/M, B/H). Size is measured as the market capitalisation at the end of the month. Within each size/price portfolio, we form a zero-investment characteristicbalanced portfolio by taking a long position in the highest CME-loading stocks and a short position in the lowest CME-loading stocks. CME (cheap minus expensive) loading of each stock is estimated by regressing monthly stock returns in the previous three year (minimum 24 months) on the CME factor and other factors as specified in model (4). A combined portfolio which is a value-weighted portfolio of all nine characteristicbalance portfolios is also formed. t-statistics are in parentheses. ", " , and ${ }^{*+*}$ denote significance levels at $10 \%, 5 \%$ and $1 \%$ respectively. 
Table 6: Nominal price anomaly in extended holding periods

\begin{tabular}{|c|c|c|c|c|}
\hline Holding period: & 2 months & 3 months & 6 months & 12 months \\
\hline \multicolumn{5}{|c|}{ Panel A: Portfolio Analysis } \\
\hline \multirow[t]{2}{*}{ Low - High } & $0.02^{* *}$ & $0.031^{\text {stot }}$ & $0.068^{* *+*}$ & $0.168^{* *+*}$ \\
\hline & $(2.354)$ & (2.968) & $(4.511)$ & $(8.400)$ \\
\hline \multicolumn{5}{|c|}{ Panel B: Fama-MacBeth regressions } \\
\hline \multirow[t]{2}{*}{$\mathrm{CP}$} & $-0.001^{* * * t}$ & $-0.001^{* * *}$ & $-0.002^{* * * *}$ & $-0.005^{* * *+}$ \\
\hline & $(-4.161)$ & $(-5.452)$ & $(-7.040)$ & $(-9.037)$ \\
\hline \multirow[t]{2}{*}{ SIZE } & -0.0002 & -0.0003 & 0.001 & 0.002 \\
\hline & $(-0.111)$ & $(-0.144)$ & $(0.292)$ & $(0.540)$ \\
\hline \multirow[t]{2}{*}{ BM } & $0.007^{*}$ & $0.009^{* *}$ & $0.013^{* *}$ & $0.021^{* * *}$ \\
\hline & $(1.897)$ & $(2.032)$ & (2.229) & (3.271) \\
\hline \multirow[t]{2}{*}{ MOM } & $0.038^{*+* t}$ & $0.051^{* *+*}$ & $0.079^{*+* x}$ & $0.101^{* * *+}$ \\
\hline & (7.301) & $(7.818)$ & $(7.765)$ & (6.899) \\
\hline \multirow[t]{2}{*}{ REV } & 0.014 & 0.036 & $0.089^{* *}$ & $0.199^{* * * *}$ \\
\hline & $(0.798)$ & $(1.581)$ & (2.573) & (4.220) \\
\hline \multirow[t]{2}{*}{ SSKEW } & $-0.0001^{\text {** }}$ & $-0.0001^{*}$ & $-0.0003^{* *}$ & -0.0002 \\
\hline & $(-2.070)$ & $(-1.707)$ & $(-2.093)$ & $(-1.340)$ \\
\hline \multirow[t]{2}{*}{ ISKEW } & -0.001 & -0.0001 & -0.006 & -0.005 \\
\hline & $(-0.539)$ & $(-0.041)$ & $(-1.329)$ & $(-0.865)$ \\
\hline \multirow[t]{2}{*}{ IVOL } & -0.411 & $-0.822^{* *}$ & $-2.075^{* * *}$ & $-4.269^{* * *+}$ \\
\hline & $(-1.601)$ & $(-2.398)$ & $(-4.222)$ & $(-6.033)$ \\
\hline \multirow[t]{2}{*}{ BETA } & -0.001 & -0.007 & $-0.023^{* * *}$ & $-0.052^{* * * *}$ \\
\hline & $(-0.299)$ & $(-1.507)$ & $(-3.903)$ & $(-5.583)$ \\
\hline \multirow[t]{2}{*}{ ILLIQ } & $1,024.04$ & $1,251.85$ & $1,527.533^{*}$ & $2,334.608^{*}$ \\
\hline & $(1.442)$ & $(1.598)$ & $(1.789)$ & $(1.844)$ \\
\hline \multirow[t]{2}{*}{ MAX } & 0.081 & 0.253 & $0.778^{* * *}$ & $1.141^{* * * x}$ \\
\hline & $(0.424)$ & $(1.177)$ & $(2.512)$ & $(2.974)$ \\
\hline $\mathrm{R}^{2}$ & 0.316 & 0.331 & 0.299 & 0.297 \\
\hline
\end{tabular}

Note: Panel A presents the differences between returns of the lowest and the highest price quintiles, assuming that the portfolios are hold in 2-, 3-, 6-, and 12-month periods. Panel B displays the Fama-MacBeth cross-sectional regressions of stock returns during the next 2-, 3-, 6-, and 12-month periods on control variables at the end of the previous month. Definitions of control variables are in Table $2 .{ }^{*}, "{ }^{* *}$, and ${ }^{* * *}$ denote significant levels of $10 \%, 5 \%$ and $1 \%$ respectively.

The estimated results from Table 5 show that 8 out of 9 portfolios exhibit negative intercepts, and 4 of them are statistically significant. The GRS F-test of Gibbons, Ross, and Shanken (1989) also rejects the joint null hypothesis that all nine intercepts are jointly equal to zero (GRSstatistics $=2.71, \mathrm{p}$-value $=0.011)$. We further combine the nine characteristic-balanced portfolios by computing their average returns and run the regression model (4). The estimations show that the intercept of this combined portfolio is negative and statistically significant at 1 percent (t-stats $=-2.709)$. Thus, our results reject the risk factor explanation of nominal price anomaly and support the mispricing hypothesis. The results imply that investors in the Vietnamese stock market irrationally overvalue stocks with low nominal prices, resulting in subsequent reversals of stock prices back to their intrinsic value. Such irrational behaviour of investors also provides evidence on the market inefficiency of the Vietnamese stock market. 


\subsection{Longer Holding Periods}

We next examine the persistence of the nominal price anomaly by extending portfolio holding periods to $2,3,6$, and 12 months. Specifically, at the end of each month, we sort stocks into quintiles based on their nominal prices and hold the portfolios for 2, 3, 6, or 12 months. Panel A of Table 6 presents the time-series averages of the differences between 2-, 3-, 6-, and 12-month returns of the lowest and the highest price quintiles. All are negative and statistically significant at 1 percent level, implying substantial long-term profitability of the strategy that buys low price and sells high price stocks. The results are robust when we apply the Fama-MacBeth multivariate regressions with the dependent variables are 2-, 3-, 6-, and 12-month returns. Specifically, Panel B of Table 6 shows that all coefficients of $C P$ are negative and strongly significant at 1 percent level, indicating that the negative effect of stock prices on returns is long-lasting. The persistent negative effect of nominal price on stock returns suggests a slow adjustment of mispriced stocks to their intrinsic value - a further evidence on the inefficiency of the Vietnamese stock market.

\section{Conclusion}

This study examines the nominal price anomaly in the Vietnamese stock market. Consistent with prior research mainly in the U.S. market, our empirical evidence shows that nominal stock price negatively affects subsequent abnormal returns, and the effect can persist up to 12 months. The results are robust in different risk models and after controlling for various stock characteristics. Further analysis suggests that the nominal price anomaly is mainly driven by mispricing, implying that investors in the market are generally irrational and might suffer from the nominal price illusion. Combined together, the evidence suggests a high level of market inefficiency in the Vietnamese stock market. Our results recognize the importance of behavioural finance, along with traditional finance, in explaining market anomaly. They also have significant implications for investors to form appropriate investment strategies, as well for firms' managers who would like to boost firm value through stock split programs.

\section{References}

Amihud, Y. (2002). Illiquidity and stock returns: cross-section and time-series effects. Journal of Financial Markets, 5(1), 31-56.

Ang, A., Hodrick, R. J., Xing, Y., \& Zhang, X. (2006). The crosssection of volatility and expected returns. The Journal of Finance, 61(1), 259-299.

Bali, T. G., Cakici, N., \& Whitelaw, R. F. (2011). Maxing out: Stocks as lotteries and the cross-section of expected returns. Journal of Financial Economics, 99(2), 427-446.
Birru, J., \& Wang, B. (2016). Nominal price illusion. Journal of Financial Economics, 119(3), 578-598.

Carhart, M. (1997). On persistence in mutual fund performance. Journal of Finance, 52(1), 57-82.

Daniel, K., Grinblatt, M., Titman, S., \& Wermers, R. (1997). Measuring mutual fund performance with characteristic-based benchmarks. The Journal of Finance, 52(3), 1035-1058.

Daniel, K., \& Titman, S. (1997). Evidence on the characteristics of cross sectional variation in stock returns. The Journal of Finance, 52(1), 1-33.

Disli, M., Inghelbrecht, K., Schoors, K., \& Stieperaere, H. (2019). Stock Price Anchoring (No. 19/966). Ghent University, Ghent, Belgium.

Dyl, E. A., \& Elliott, W. B. (2006). The share price puzzle. The Journal of Business, 79(4), 2045-2066.

Edmister, R. O., \& Greene, J. B. (1980). Performance of Superlow-price Stocks. The Journal of Portfolio Management, 7(1), $36-41$

Fama, E. F., \& French, K. R. (1993). Common Risk Factors in the Returns on Stocks and Bonds. Journal of Financial Economics, 33(1), 3-56.

Fama, E. F., \& MacBeth, J. D. (1973). Risk, Return, and Equilibrium: Empirical Tests. Journal of Political Economy, 81(3), 607-636.

Goodman, D. A., \& Peavy, J. W. (1986). The low price effect: Relationship with other stock market anomalies. Review of Financial Economics, 22(1), 18-26.

Green, T. C., \& Hwang, B.-H. (2009). Price-based return comovement. Journal of Financial Economics, 93(1), 37-50.

Harvey, C. R., \& Siddique, A. (2000). Conditional skewness in asset pricing tests. The Journal of Finance, 55(3), 1263-1295.

Hirshleifer, D., Hou, K., \& Teoh, S. H. (2012). The accrual anomaly: risk or mispricing? Management Science, 58(2), 320-335.

Hoang, L. T., \& Phan, T. T. (2019). Is liquidity priced in the Vietnamese stock market? Economic Papers, The Economic Society of Australia,38(3), 193-207. DOI: 10.1111/17593441.12249

Hwang, S., \& Lu, C. (2008). Is Share Price Relevant? SSRN Working Paper. Retrieved from https://ssrn.com/abstract=1341790.

Lintner, J. (1965). The Valuation of Risk Assets and the Selection of Risky Investments in Stock Portfolios and Capital Budgets. Review of Economics and Statistics, 47(1), 13-37.

Nartea, G. V., Kong, D., \& Wu, J. (2017). Do extreme returns matter in emerging markets? Evidence from the Chinese stock market. Journal of Banking \& Finance, 76, 189-197.

Nguyen, C. T., \& Nguyen, M. H. (2019). Modeling Stock Price Volatility: Empirical Evidence from the Ho Chi Minh City Stock Exchange in Vietnam. Journal of Asian Finance, Economics and Business, 6(3), 19-26. https://doi.org/10.13106/ jafeb.2019.vol6.no3.19

Nguyen, D., \& Pham, M. (2018). Search-based sentiment and stock market reactions: an empirical evidence in Vietnam. Journal 
of Asian Finance, Economics and Business, 5(4), 45-56. http:// doi.org/10.13106/jafeb.2018.vol5.no4.45

Pastusiak, R., Jasiniak, M., \& Plustoka, A. (2019). Low Price Anomaly in M\&A Transactions. Ekonomický Časopis, 67, 195214.

Schultz, P. (2000). Stock splits, tick size, and sponsorship. The Journal of Finance, 55(1), 429-450.
Vu, V. T. T., Phan, N. T., \& Dang, H. N. (2020). Impacts of Ownership Structure on Systemic Risk of Listed Companies in Vietnam. Journal of Asian Finance, Economics, and Business, 7(2), 107117. https://doi.org/10.13106/jafeb.2020.vol7.no2.107

Zaremba, A., Okoń, S., Nowak, A., \& Konieczka, P. (2016). The low price anomaly: The intriguing case of the Polish Stock Market. Inzinerine Ekonomika-Engineering Economics, 27(2), 163-174. 